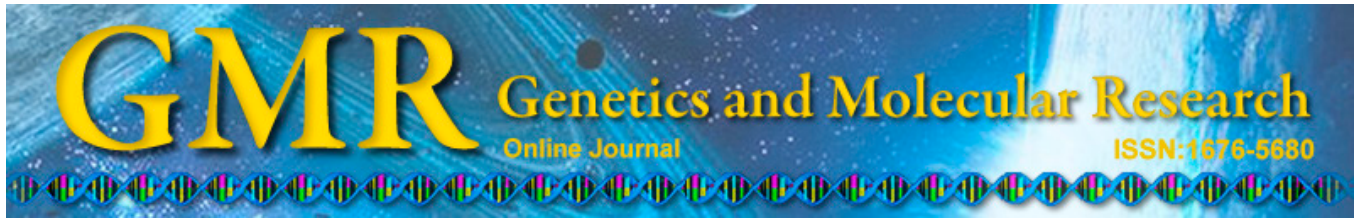

\title{
Association of MyoDla and MyoDlb gene polymorphisms and meat quality traits in rainbow trout
}

\author{
W.X. Chen" ${ }^{1,2}$, Y. Ma ${ }^{1}$ and K.H. Liu' ${ }^{2}$ \\ ${ }^{1}$ School of Food Science and Technology, Harbin Institute of Technology, \\ Harbin, China \\ ${ }^{2}$ Animal Institute of Science and Technology, Northeast Agricultural University, \\ Harbin, China \\ Corresponding author: Y. Ma \\ E-mail: maying@hit.edu.cn
}

Genet. Mol. Res. 14 (3): 9034-9044 (2015)

Received December 1, 2014

Accepted May 23, 2015

Published August 7, 2015

DOI http://dx.doi.org/10.4238/2015.August.7.12

\begin{abstract}
In this study, we identified myogenic regulatory factors $(M R F s)$ and analyzed the correlation between $M R F s$ and meat quality in rainbow trout. The MyoDla and MyoDlb genes were cloned from rainbow trout using a homology cloning method. Introns 1 and 2 in the MyoDla and MyoDlb genes were cloned and submitted to GenBank (accession Nos. FJ623462 and FJ793566). Polymorphisms of MyoDla and MyoD1b genes were analyzed using single-strand conformation polymorphism and sequencing, respectively. Two single nucleotide polymorphisms were detected in the $M y o D 1$ gene, located at $129 \mathrm{G} \rightarrow \mathrm{A}$ in exon 1 and $37 \mathrm{G} \rightarrow \mathrm{A}$ in exon 2 . The $37 \mathrm{G} \rightarrow$ A mutation in exon 2 induced the $\mathrm{R} 185 \mathrm{~K}$ amino acid change in the polypeptide chain. Seven single nucleotide polymorphisms in the MyoD2 gene were detected, including $218 \mathrm{~T} \rightarrow \mathrm{C}, 224 \mathrm{~T} \rightarrow \mathrm{C}$, $242 \mathrm{~A} \rightarrow \mathrm{C}, 246 \mathrm{~T} \rightarrow \mathrm{A}, 248 \mathrm{~T} \rightarrow \mathrm{C}, 305 \mathrm{~T} \rightarrow \mathrm{C}$, and $329 \mathrm{C} \rightarrow \mathrm{T}$. The $246 \mathrm{~T} \rightarrow \mathrm{A}$ mutation in exon 1 induced the $\mathrm{R} 83 \mathrm{~K}$ change in the polypeptide chain. In the $\mathrm{S} 3$ fragment, meat quality traits of genotypes $\mathrm{AA}$ and $\mathrm{AB}$ significantly differed from those of genotype $\mathrm{BB}(\mathrm{P}<0.05)$. In the S5 fragment, meat
\end{abstract}


quality traits of the genotypes $\mathrm{AA}$ and $\mathrm{AC}$ were significantly different from the genotypes $\mathrm{BB}$ and $\mathrm{BC}(\mathrm{P}<0.05)$. These results indicate that the $M y o D l a$ and $M y o D 1 b$ genes have an important influence on meat quality or were linked to the major genes in these strains. These genes can be used to control muscle fiber traits in rainbow trout, and the mutations in the S3 and S5 fragments can be used as molecular markers for selecting rainbow trout with better meat quality traits.

Key words: Meat quality; Myogenic regulatory factor; Rainbow trout; Myogenic determining factor; Polymorphism

\section{INTRODUCTION}

The myogenic regulatory factors $(M R F s)$ are a family of vertebrate proteins that are potent transcription factors for muscle genes (Pownall et al., 2002). The myogenic determining factor $(M y O D)$ gene belongs to the $M R F$ gene family, which initiates and maintains the differentiation and development of skeletal muscle during myogenesis (Weintraub et al., 1993). In higher vertebrates, the $M R F$ gene family includes 4 members, MyoD, Myf5, myogenin, and MRF4, which together induce the differentiation and development of pre-myoblasts to form muscle fiber (Olson et al, 1991; Buckingham, 1992). Myf5, in combination with MyoD1, determine the muscular lineage and is the first factor in this family to be expressed in the embryo (Braun et al., 1989, 1990). The presence of a very mild muscle phenotype in mice containing null mutations in MyoD1 likely occurred because of a compensatory effect of Myf5 (Rudnicki et al., 1992). The double-mutant mice died soon after birth because of a lack of muscle structure, highlighting the importance of these 2 proteins in establishing the myogenic lineage (Rudnicki et al., 1993). Over-expression of the $M y O D 1$ gene inhibits the proliferation process of myoblasts and promotes the differentiation of myoblasts to form mature muscle fiber cells (Kablar et al., 1997). Myogenin gene activity was affected by the MyoDl gene, and indirectly affected the terminal differentiation process of muscle cell (Weintraub, 1993). Previous studies suggested that myogenin and MyoDl are also involved in establishing and maintaining the slow-twitch and fast-twitch mature muscle fiber phenotype; myogenin was expressed at higher levels compared with MyoD1 in slow-twitch muscles, whereas the opposite was true for fast-twitch muscles (Hughes et al., 1993; Voytik et al., 1993). Muscle fiber characteristics play a key role in meat quality (Picard et al., 2002). All MyoD in rainbow trout and Atlantic salmon are thought to be $M y o D l$ (a, b, c), whereas MyoD2 exists only in non-salmonid fish species (Macqueen and Johnston, 2008). The cDNA sequences of MyoDla and MyoD1b were not products of true alleles, but originate from 2 loci that were likely duplicated during the tetraploidization of the whole salmonid genome. The MyoDlb gene shows high conservation with the MyoDla gene in the basic helix-loop-helix domain, and their respective coding regions are located at the 3'- and 5'-ends of genes on the nucleotide level. The MyoDla and MyoDlb genes in rainbow trout were found to be co-expressed, but the large differences in the coding region and non-coding region indicated that they come from different loci (Rescan and Gauvry, 1996).

New types of molecular markers are needed for the selection of meat production ability and meat quality in live animals. A recent correlation study on MyoD1 gene and meat quality traits was mainly concentrated in pig (Knoll et al., 1997). Intron 1 of the MyoDl gene contains a $D d e$ I polymorphic locus in the pig, which plays a role in increasing muscle fiber 
area, lean meat percentage, carcass length, loin eye area, and leg proportion (Knoll et al., 1997). However, this mutant can also lead to meat quality deterioration. Kim et al. (2009) identified a new single nucleotide polymorphism (SNP) site in the 5'-upstream region of the myogenin gene (nucleotides $\mathrm{C}$ and $\mathrm{T}$ ). A total of 252 pigs of 3 breeds were genotyped by polymerase chain reaction (PCR)-restriction fragment length polymorphism using $B s p$ CNI (restriction enzymes). Additionally, the pigs were genotyped for the previously detected $M s p$ I site in the 3'-flanking region (alleles A and B). The CCBB diplotype showed the highest frequency among the breeds, followed by TCBB and CCAB. Association analysis performed for the markers showed that the TCBB diplotype had desirable effects on the total number of fibers $(\mathrm{P}<0.002)$, fiber cross-sectional area $(\mathrm{P}<0.06)$, and loin eye area $(\mathrm{P}<0.001)$ compared to the other diplotypes. Correlation analysis of the MyoDIa and MyoDIb genes with fish meat quality has not been previously reported. In this study, the MyoDla and MyoDlb gene sequences of rainbow trout and Atlantic salmon (Rescan and Gauvry, 1996) were used to analyze polymorphisms of genes, explore the distribution of different genotypes, and further reveal the functions of genes. The relationship between the MyoDla and MyoDlb genes in rainbow trout and meat quality traits will be examined in further studies, and molecular genetic markers will be identified, thus providing a basis for molecular marker-assisted selection.

\section{MATERIAL AND METHODS}

\section{Samples}

One hundred healthy rainbow trout, with body weights of approximately 130-150 g, were provided by the Bohai Experiment Station of Cold-Water Fish, Heilongjiang River Fishery Research Institute of Chinese Academy of Fishery Sciences. The muscle from the dorsal fin base was selected for further analysis of meat quality.

\section{DNA isolation}

Genomic DNA was extracted from fin samples of rainbow trout using the Qiagen DNAeasy kit (Hilden, Germany). The quality and concentration of DNA were assessed by agarose gel electrophoresis and measured using an ultraviolet RNA/DNA spectrophotometer (Shanghai Spectrum Instruments Co., Ltd., Shanghai, China). Finally, DNA was adjusted to $50 \mathrm{ng} / \mu \mathrm{L}$ and was stored at $4^{\circ} \mathrm{C}$ until future use.

\section{Primer design, PCR amplification, and sequencing}

According to reported DNA sequences of rainbow trout (GenBank accession Nos. X75798, Z46924) and Atlantic salmon (GenBank accession Nos. AJ557148, AJ557149), the primers M1-M5 were designed to amplify the DNA sequences of the MyoDla and MyoD1b genes. According to DNA sequences obtained, the 11 pairs of primers (S1-S11) were designed for PCR-single-strand conformation polymorphism (SSCP) analysis. The primer names, primer sequences, and length of products amplified are shown in Table 1. 
Table 1. Primers of MyoDla and MyoD1b used for rainbow trout.

\begin{tabular}{|c|c|c|c|c|c|}
\hline Gene & Primer name & Primer sequence $\left(5^{\prime}-3^{\prime}\right)$ & Location & Product length & Annealing temperature \\
\hline \multirow[t]{12}{*}{ MyoDla } & \multirow[t]{2}{*}{ M1 } & & \multirow[t]{2}{*}{ Exon 1} & \multirow[t]{2}{*}{393} & \multirow[t]{2}{*}{$47^{\circ} \mathrm{C}$} \\
\hline & & R-GGGACAGGCAGAGGTAT & & & \\
\hline & \multirow[t]{2}{*}{ M2 } & F-ACGGAATGGTGAGAAACT & Intron 1 & \multirow[t]{2}{*}{621} & \multirow[t]{2}{*}{$60^{\circ} \mathrm{C}$} \\
\hline & & R-GGGACAGGCAGAGGTAT & Exon 2 & & \\
\hline & \multirow{2}{*}{$\mathrm{S} 1$} & F-CGTCTACTAACCCAAACC & Exon 1 & \multirow{2}{*}{187} & \multirow[t]{2}{*}{$57^{\circ} \mathrm{C}$} \\
\hline & & R-ACCATTCCGTCTGAGC & & & \\
\hline & \multirow[t]{2}{*}{$\mathrm{S} 2$} & F-AACTGCTCAGACGGAA & Intron 1 & \multirow[t]{2}{*}{178} & \multirow[t]{2}{*}{$55^{\circ} \mathrm{C}$} \\
\hline & & R-TTGGTGGACAAGACTGA & & & \\
\hline & \multirow[t]{2}{*}{$\mathrm{S} 3$} & F-GACGGAGAAACAAGTAT & Exon 2 & \multirow[t]{2}{*}{241} & \multirow{2}{*}{$57^{\circ} \mathrm{C}$} \\
\hline & & R-CCACATCATAGCAAAAC & Intron 2 & & \\
\hline & \multirow[t]{2}{*}{ S4 } & F-GAGTATATTTGACCCAG & Intron 2 & \multirow[t]{2}{*}{235} & \multirow[t]{2}{*}{$50^{\circ} \mathrm{C}$} \\
\hline & & R-CAGAGTTCTTCTTGTG & & & \\
\hline \multirow[t]{20}{*}{$M y o D I b$} & \multirow[t]{2}{*}{ M3 } & F-TGTGACAAATACAGAGCC & Exon 1 & \multirow[t]{2}{*}{721} & \multirow[t]{2}{*}{$47^{\circ} \mathrm{C}$} \\
\hline & & R-TATCCGATTGGTAGTTCC & & & \\
\hline & \multirow[t]{2}{*}{ M4 } & F-AACTGCTCAGACGGAA & Exon 2 & \multirow[t]{2}{*}{568} & \multirow[t]{2}{*}{$47^{\circ} \mathrm{C}$} \\
\hline & & R-TCGTTGAAGTAGGTGC & & & \\
\hline & \multirow[t]{2}{*}{ M5 } & F-TCGCCGAAACTCCAAAT & Intron 2 & \multirow[t]{2}{*}{569} & \multirow[t]{2}{*}{$46^{\circ} \mathrm{C}$} \\
\hline & & R-GCCATCCTCTTCTTCTACT & Exon 3 & & \\
\hline & S5 & F-GTGAGATGGAGTTGTCG & Exon 1 & 283 & $50^{\circ} \mathrm{C}$ \\
\hline & & R-TCCCGCATAGTAGCAG & & & \\
\hline & S6 & F-CGAAGACGAGCACATC & Exon 1 & 218 & $50^{\circ} \mathrm{C}$ \\
\hline & & R-TCTCCACCTTGGGAAG & & & \\
\hline & S7 & F-CGAGAACCTGAAGAGA & Exon 1 & 193 & $50^{\circ} \mathrm{C}$ \\
\hline & & R-AGAGCAGTTGGACTGT & & & \\
\hline & S8 & F-CATCCAGTCCACAGTC & Intron 1 & 192 & $53^{\circ} \mathrm{C}$ \\
\hline & & R-TATCCGATTGGTAGTTCC & & & \\
\hline & S9 & F-GGAACTACCAATCGGA & Exon 2 & 256 & $56^{\circ} \mathrm{C}$ \\
\hline & & R-GCCTAACAAGTCACAAT & Intron 1,2 & & \\
\hline & $\mathrm{S} 10$ & F-AAGACCCTTGGCAGACAT & Intron 2 & 251 & $53^{\circ} \mathrm{C}$ \\
\hline & & R-CCGTTTCGCTCAGGATA & & & \\
\hline & S11 & F-ATCTATCCTGAGCGAA & Exon 3 & 200 & $49^{\circ} \mathrm{C}$ \\
\hline & & R-GCCATCCTCTTCTTCTA & & & \\
\hline
\end{tabular}

$\mathrm{F}=$ forward primer; $\mathrm{R}=$ reverse primer.

DNA sequences of the MyoDla and MyoD1b genes were amplified using the M1-M5 primers. The $25-\mu \mathrm{L}$ PCR mixture contained $0.1 \mu \mathrm{L}$ of each primer, $2.5 \mu \mathrm{L} 10 \mathrm{X}$ PCR buffer, $2.0 \mu \mathrm{L}$ dNTP, $0.2 \mu \mathrm{L}$ Taq polymerase (Takara, Shiga, Japan), and $1 \mu \mathrm{L}$ DNA template. PCRs were performed on PCR machine (PTC-200; MJ Research, Waltham, MA, USA). The PCR conditions were as follows: pre-denaturation at $94^{\circ} \mathrm{C}$ for $4 \mathrm{~min}$; 35 cycles of denaturation at $94^{\circ} \mathrm{C}$ for $30 \mathrm{~s}$, annealing at $54.8^{\circ}-60.1^{\circ} \mathrm{C}$ (Table 1) for $30 \mathrm{~s}$, and extension at $72^{\circ} \mathrm{C}$ for $1 \mathrm{~min}$, with a final extension at $72^{\circ} \mathrm{C}$ for $10 \mathrm{~min}$. The products were cloned into the $\mathrm{pUCm}-\mathrm{T}$ cloning vector and sequenced by a commercial sequencing service.

\section{PCR-SSCP analysis}

Polymorphisms in the MyoD $1 a$ and MyoDIb genes were identified using the SSCP method. First, $2 \mu \mathrm{L}$ PCR product was mixed with $6 \mu \mathrm{L}$ sample buffer $(9.8 \mathrm{~mL}$ formamide, 0.2 $\mathrm{mL}$ 0.5 M EDTA, pH 8.0, $0.2 \mathrm{~mL}$ glycerol, $0.025 \%$ bromophenol blue, $0.025 \%$ xylene blue), and then the gel was quickly placed in ice and cooled for $10 \mathrm{~min}$ after denaturation for $10 \mathrm{~min}$ at $98^{\circ} \mathrm{C}$. Fragments were subjected to electrophoresis for $12 \mathrm{~h}$ at a constant voltage of $120 \mathrm{~V}$ at room temperature and then silver-stained. 


\section{Analysis of meat quality traits}

Samples were paraffin-sectioned for analysis of muscle fiber density and muscle fiber diameter. The fresh muscle in the dorsal fin base of rainbow trout was fixed in Bouin's fixative for $24 \mathrm{~h}$. After dehydration in a series of increasing concentrations of ethanol, specimens were embedded in paraffin, cut into $6-\mu \mathrm{m}$ thick transverse sections, and stained with hematoxylineosin. The sections were examined under a Moctic DM-BA300-B microscope (Hong Kong, China) and analyzed using Motic Images Advanced 3.2. The cross-sectional areas ( $\mathrm{Si}$ ) of muscle fibers were measured at random and the single diameter (Ds) and average diameter (Da) of muscle fibers were calculated using the following equation:

$$
D \mathrm{~s}=2(\mathrm{Si} /)^{0.5} \quad D \mathrm{a}=\sum D i / 50 \quad \text { (Equation 1) }
$$

Dry matter content of fresh muscle was measured using the drying temperature dehydration method. The protein content of fresh muscle was measured using the Micro-Kjeldahl method. Intramuscular fat content of fresh muscle was measured by Soxhlet extraction. Crude ash content of fresh muscle was measured using the conventional muffle furnace method $\left(550^{\circ} \mathrm{C}\right)$ (Liang et al., 2009).

\section{Statistical analysis}

The distribution of the genotypes was tested for Hardy-Weinberg equilibrium as described by Falconer and Mackay (1996). Associations between genotypes and meat quality traits were evaluated using SPSS13.0 (SPSS, Inc., Chicago, IL, USA).

\section{RESULTS}

\section{PCR amplification of MyoD1a and MyoD1b genes}

The primers M1 and M2 amplified approximately 400-bp (Figure 1a) and 600-bp (Figure 1b) fragments. The 751-bp MyoDla gene sequence was obtained by sequencing, comparison, and splicing, and included $129 \mathrm{bp}$ of intron 1 and $296 \mathrm{bp}$ of intron 2. The primers M3, M4, and M5 amplified approximately 750-bp (Figure 1c) and 600-bp fragments (Figure 1d and 1e). The length of the 1471-bp MyoD1b gene sequences was obtained through sequencing, comparison, and splicing, and included $271 \mathrm{bp}$ of intron 1 and $197 \mathrm{bp}$ of intron 2. Introns 1 and 2 of the MyoDla and MyoDlb genes were cloned and submitted to GenBank with accession Nos. FJ623462 for MyoD1a and FJ793566 for MyoD1b. The 11 pairs of SSCP primers used for SSCP analysis showed good amplification. The figures of agarose detection were omitted.

\section{Polymorphism analysis of MyoD1a and MyoD1b genes}

The PCR-amplified fragment of primer S2 showed 3 genotypes (AA, BB, and AB) (Figure 2), and the homozygous individuals of the 2 genotypes were sequenced and showed an $\mathrm{A} / \mathrm{G}$ mutation at position $129 \mathrm{bp}$ of the genotype AA sequence in intron 1 of the MyoDla gene. The genotype BB sequence showed consensus with the sequence of the MyoDla gene. 


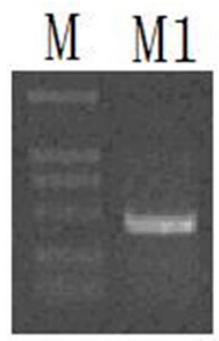

a

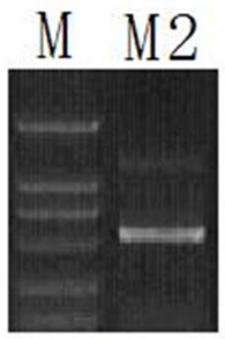

b

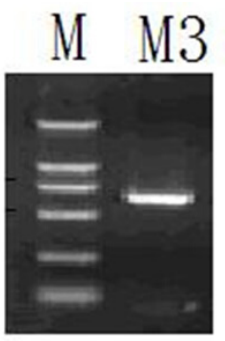

C

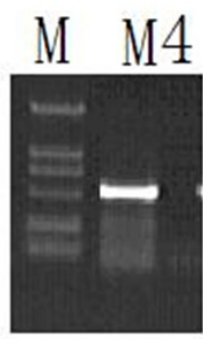

d

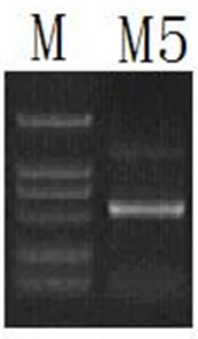

e

Figure 1. PCR amplification using primers M1, M2, M3, M4, and M5. a. 400 bp; b. 600 bp; c. 750 bp; d. 600 bp; e. $600 \mathrm{bp}$.

$$
\mathrm{AB} \cdot \mathrm{BB} \cdot \mathrm{BB} \cdot \mathrm{BB} \cdot \mathrm{AB} \cdot \mathrm{AA}
$$
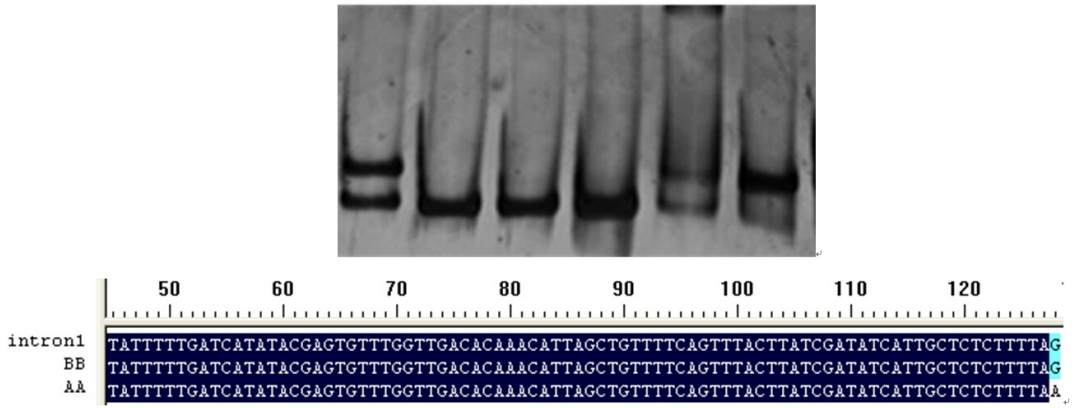

Figure 2. PCR-SSCP pattern and sequence comparison of different genotypes using the S2 primer.

The PCR-amplified fragment of primer S3 showed 3 genotypes (AA, BB, and AB) (Figure 3 ), and the homozygous individuals of the 2 genotypes were sequenced and showed an $\mathrm{A} / \mathrm{G}$ mutation at position $37 \mathrm{bp}$ of the genotype AA sequence in exon 1 of the MyoDla gene (Figure 3). This mutation induced an R185K amino acid change in the protein polypeptide chain (Figure 3).

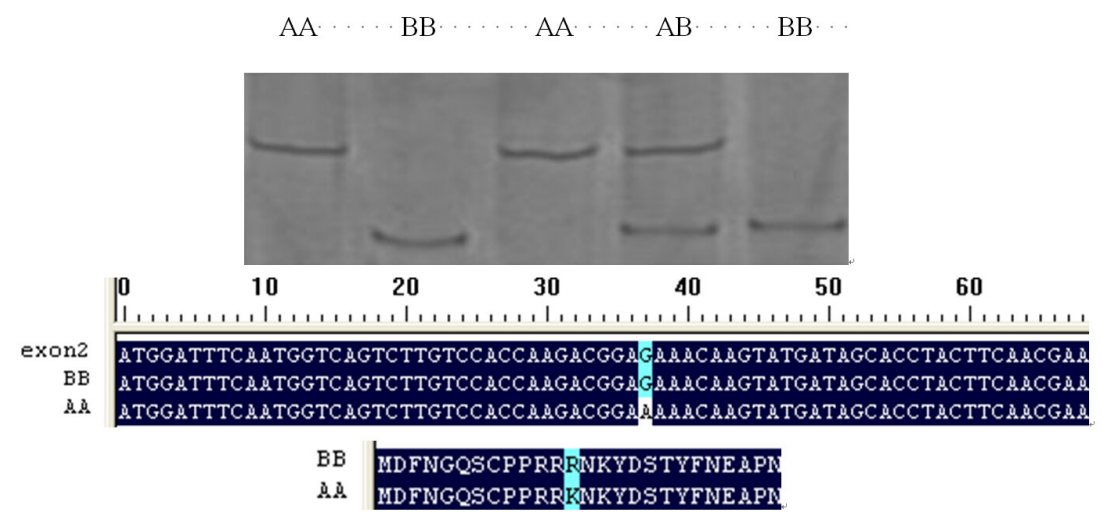

Figure 3. PCR-SSCP pattern and sequence comparison of different genotypes using the S3 primer. 
The PCR-amplified fragment of primer S5 showed 4 genotypes (AA, BB, AC, and CC) (Figure 4), and the homozygous individuals of the 3 genotypes were sequenced, revealing $5 \mathrm{mu}$ tations, including $3 \mathrm{~T} / \mathrm{C}$ mutations at positions 218,224 , and $248 \mathrm{bp}$, an $\mathrm{A} / \mathrm{C}$ mutation at position 224, and a T/A mutation at position 246 bp in exon 1 of the MyoDlb gene (Figure 4). The T247A mutation induced an R83K amino acid change in the protein polypeptide chain (Figure 4).

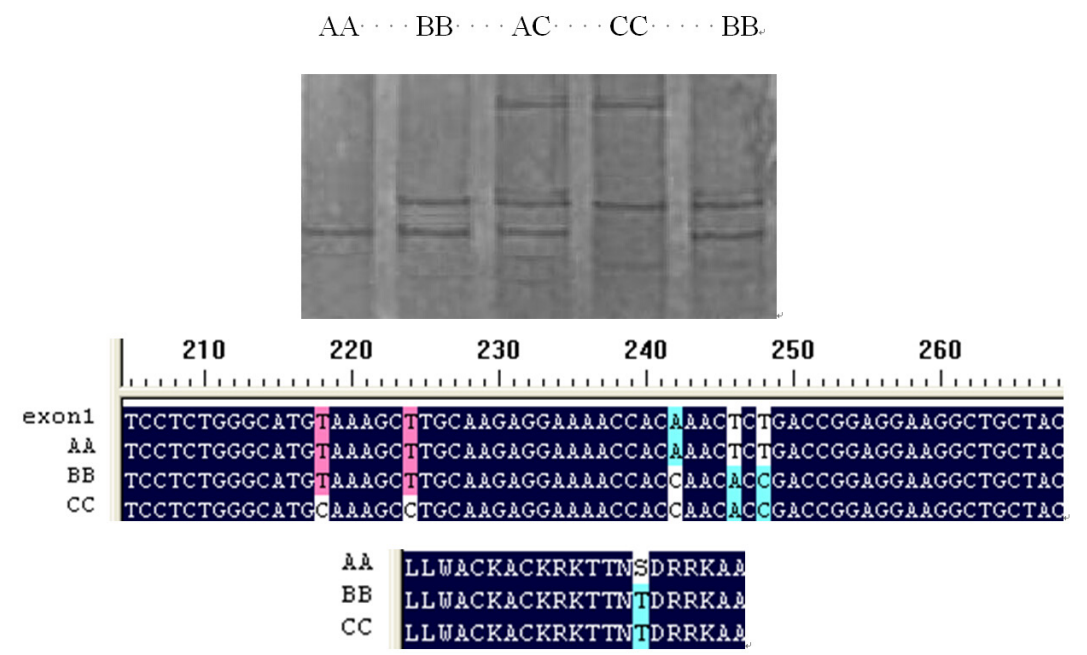

Figure 4. PCR-SSCP pattern and sequence comparison of different genotypes using the rainbow trout S5 primer.

The PCR amplified fragment of primer S6 showed 6 genotypes (AA, BB, CC, AB, $\mathrm{AC}$, and $\mathrm{BC}$ ) (Figure 5). The homozygous individuals of the 3 genotypes were sequenced, revealing 2 mutations, including a $\mathrm{T} / \mathrm{C}$ mutation at position $305 \mathrm{bp}$ and a $\mathrm{C} / \mathrm{T}$ mutation at position $329 \mathrm{bp}$ in exon 1 of the MyoDlb gene (Figure 5).
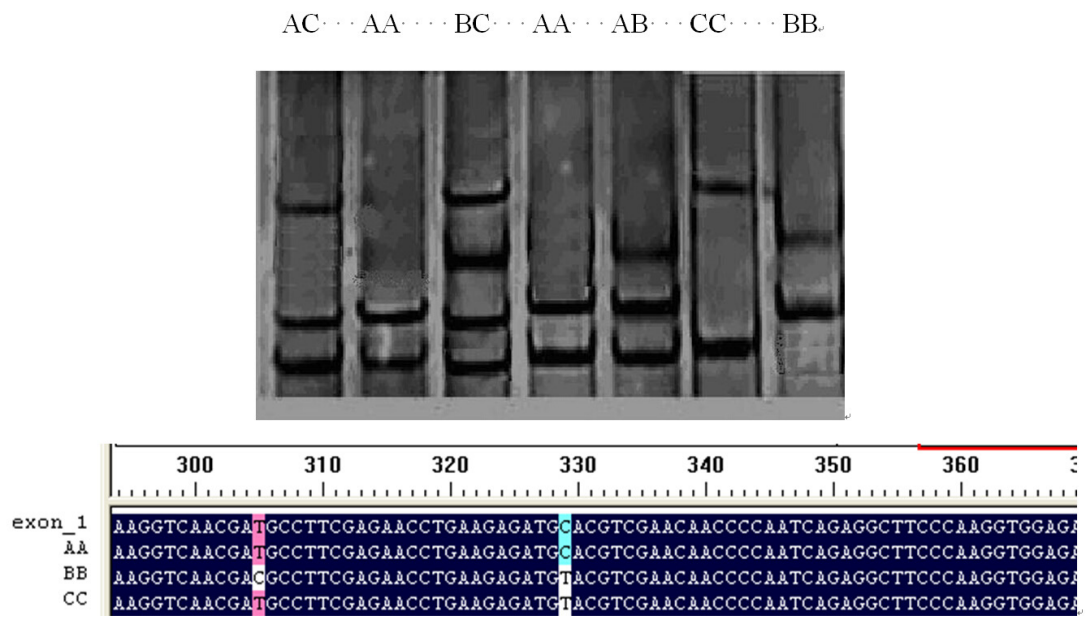

Figure 5. PCR-SSCP pattern and sequence comparison of different genotypes using the S6 primer. 


\section{Gene and genotype frequency}

The gene and genotype frequencies of the S2, S3, S5, and S6 polymorphic loci were analyzed (Table 2). In the S2 and S5 loci, allele A was the dominant allele. In S3 and S6, the genotypes were evenly distributed.

\begin{tabular}{|c|c|c|c|c|c|c|c|c|c|c|c|c|c|c|}
\hline \multirow[t]{2}{*}{ Gene } & \multirow[t]{2}{*}{ Primers } & \multicolumn{6}{|c|}{ Genotype frequency } & \multicolumn{3}{|c|}{ Allele frequency } & \multirow[t]{2}{*}{$H_{\mathrm{O}}$} & \multirow[t]{2}{*}{$H_{\mathrm{E}}$} & \multirow[t]{2}{*}{$N_{\mathrm{E}}$} & \multirow[t]{2}{*}{ PIC } \\
\hline & & $\mathrm{AA}$ & $\mathrm{AB}$ & BB & $\mathrm{AC}$ & $\mathrm{BC}$ & $\mathrm{CC}$ & A & B & $\mathrm{C}$ & & & & \\
\hline MyoDla & S2 & $\begin{array}{c}0.620 \\
(62)\end{array}$ & $\begin{array}{c}0.230 \\
(23)\end{array}$ & $\begin{array}{r}0.150 \\
(15)\end{array}$ & & & & 0.735 & 0.265 & & 0.610 & 0.390 & 1.64 & 0.314 \\
\hline MyoDla & S3 & $\begin{array}{c}0.340 \\
(34)\end{array}$ & $\begin{array}{c}0.250 \\
(25)\end{array}$ & $\begin{array}{r}0.410 \\
(41)\end{array}$ & & & & 0.465 & 0.535 & & 0.502 & 0.498 & 1.99 & 0.374 \\
\hline MyoDIb & S5 & $\begin{array}{c}0.490 \\
(49)\end{array}$ & 0.000 & $\begin{array}{c}0.090 \\
(9)\end{array}$ & $\begin{array}{c}0.270 \\
(27)\end{array}$ & & $\begin{array}{c}0.150 \\
(15)\end{array}$ & 0.625 & 0.09 & 0.285 & 0.480 & 0.520 & 2.08 & 0.449 \\
\hline MyoDIb & S6 & $\begin{array}{c}0.130 \\
(13)\end{array}$ & $\begin{array}{c}0.330 \\
(33)\end{array}$ & $\begin{array}{r}0.140 \\
(14)\end{array}$ & $\begin{array}{c}0.100 \\
(20)\end{array}$ & $\begin{array}{c}0.090 \\
(9)\end{array}$ & $\begin{array}{c}0.110 \\
(11)\end{array}$ & 0.395 & 0.350 & 0.255 & 0.329 & 0.671 & 3.03 & 0.582 \\
\hline
\end{tabular}

*Number of individuals are shown in parentheses.

\section{Genetic polymorphism analysis in different loci of MyoD1a and MyoD1b genes}

Polymorphic information content (PIC) of S2, S3, and S5 showed moderate polymorphism, $0.25<\mathrm{PIC}<0.5$. The S6 locus of the MyoD $1 b$ gene showed a high level of polymorphism $(\mathrm{PIC}=0.582)$. This result indicates that this locus has a higher degree of genetic variability and larger selective potential than other loci.

\section{Association between SNPs and meat quality traits of rainbow trout}

One hundred healthy rainbow trout were screened using PCR-SSCP. The different genotypes produced by the S2 and S6 loci were not significantly associated with meat quality traits $(\mathrm{P}>0.05)$. Table 3 shows that the crude protein at the $\mathrm{S} 3$ locus was not significantly different $(P>0.05)$. However, the muscle fiber density and dry matter content of genotypes $\mathrm{AA}$ and $\mathrm{AB}$ were significantly higher than of genotype $\mathrm{BB}(\mathrm{P}<0.05)$, and the muscle fiber diameter was significantly lower than in genotype $\mathrm{BB}(\mathrm{P}<0.05)$.

\section{Table 3. Effect of different genotypes in $\mathrm{S} 3$ and $\mathrm{S} 5$ on meat quality traits in rainbow trout.}

\begin{tabular}{|c|c|c|c|c|c|c|c|}
\hline \multirow[t]{2}{*}{ Traits } & \multicolumn{3}{|c|}{ Genotype of S3 } & \multicolumn{4}{|c|}{ Genotype of S5 } \\
\hline & AA & $\mathrm{AB}$ & BB & AA & $\mathrm{AC}$ & BB & $\mathrm{CC}$ \\
\hline Dry matter $(\%)$ & $31.21 \pm 1.52^{\mathrm{a}}$ & $30.82 \pm 2.20^{\mathrm{a}}$ & $28.17 \pm 1.89^{b}$ & $31.56 \pm 1.32^{\mathrm{a}}$ & $30.45 \pm 1.78^{\mathrm{a}}$ & $28.97 \pm 1.90^{\mathrm{b}}$ & $29.53 \pm 1.11^{\mathrm{b}}$ \\
\hline Protein $(\%)$ & $17.29 \pm 0.62$ & $17.63 \pm 0.55$ & $16.58 \pm 0.31$ & $17.33 \pm 0.21$ & $17.74 \pm 0.11$ & $17.01 \pm 0.87$ & $17.56 \pm 0.44$ \\
\hline Intramuscular fat content (\%) & $11.24 \pm 0.50$ & $10.67 \pm 0.41$ & $12.11 \pm 0.67$ & $11.67 \pm 0.39$ & $10.99 \pm 0.36$ & $11.32 \pm 0.41$ & $11.01 \pm 0.25$ \\
\hline Ash (\%) & $2.49 \pm 0.04$ & $2.45 \pm 0.03$ & $2.46 \pm 0.04$ & $2.52 \pm 0.03$ & $2.56 \pm 0.04$ & $2.54 \pm 0.03$ & $2.51 \pm 0.03$ \\
\hline Muscle fiber density $\left(\mathrm{N} / \mathrm{mm}^{2}\right)$ & $293.63 \pm 46.33^{\mathrm{a}}$ & $268.97 \pm 79.14^{\mathrm{a}}$ & $241.32 \pm 56.25^{\mathrm{b}}$ & $269.22 \pm 56.12$ & $271.02 \pm 63.83^{\mathrm{a}}$ & $257.73 \pm 42.78^{\mathrm{b}}$ & $256.54 \pm 50.88^{b}$ \\
\hline Muscle fiber diameter $(\mu \mathrm{m})$ & $29.67 \pm 2.63^{\mathrm{a}}$ & $30.12 \pm 1.98^{\mathrm{a}}$ & $32.53 \pm 1.14^{\mathrm{b}}$ & $28.14 \pm 2.35^{\mathrm{a}}$ & $27.75 \pm 1.65^{\mathrm{a}}$ & $30.87 \pm 1.05^{\mathrm{b}}$ & $31.17 \pm 1.83^{\mathrm{b}}$ \\
\hline
\end{tabular}

Different letters indicate significant difference at 0.05 levels. 
In S5 locus, the crude protein, intramuscular fat, and ash among different genotypes were not significantly different $(\mathrm{P}>0.05$; Table 3 ). However, dry matter content and muscle fiber density of genotypes AA and AC were significantly higher than in genotypes $\mathrm{BB}$ and $\mathrm{CC}$ $(\mathrm{P}<0.05)$. Muscle fiber diameters of genotypes $\mathrm{BB}$ and $\mathrm{CC}$ were significantly greater than in genotypes $\mathrm{AA}$ and $\mathrm{AC}(\mathrm{P}<0.05$; Table 3$)$.

\section{DISCUSSION}

The aim of breeding programs has changed from increasing yield to improving meat quality-related traits (van Wijk et al., 2005). A study examining the association of these traits and candidate genes increased the understanding of the genetic basis of productive traits (Óvilo et al., 2006). The development process of muscle is controlled by the $M y o D$ gene family (Massari and Murre, 2000). MRFs play important roles in muscle precursor cell shape, as well as muscle fiber formation, until individual functions mature after birth (te Pas and Visscher, 1994). The MyoDl gene was first identified in the human genome (Davis et al., 1987). Two distinct $M R F s$ with homology to MyoD (MyoDla and MyoDlb genes) in rainbow trout were isolated by Rescan in 1996. In this study, the intron 1 and 2 sequences of the MyoDla and MyoD1b genes were cloned and submitted to GenBank (accession Nos. FJ623462 and FJ793566).

Numerous studies have examined MyoD1 gene polymorphisms, mainly focusing on pigs (Knoll et al., 1997; Urbański and Kuryl, 2004; Wyszyńska-Koko et al., 2006; Kim et al., 2009), cattle (Tian et al., 2007), and other animals (Zhang et al., 2007); however, there have been no reports in fish. In the pig, 2 polymorphic loci (C489T and G566C) were detected at 333 and $62 \mathrm{bp}$ of exon 1, and the G566C mutation caused an exchange of arginine to proline (Urbański and Kuryl, 2004). In cattle, intron 2 of the MyoD1 gene was found to contain 2 polymorphic loci, C39T and C112G (Tian et al., 2007). Seven SNP loci in introns were identified in the $M y o D$ gene using the PCR-SSCP technique and sequencing in Micropterus salmoides (Yu et al., 2009). In this study, 2 SNP loci of the MyoDla gene were detected, located at $129 \mathrm{G} \rightarrow \mathrm{A}$ in exon 1 and $37 \mathrm{G} \rightarrow \mathrm{A}$ in exon 2 . The $37 \mathrm{G} \rightarrow \mathrm{A}$ mutation in exon 2 induced an $\mathrm{R} 185 \mathrm{~K}$ amino acid change in the protein polypeptide chain. Seven SNPs in the MyoD $1 b$ gene were detected and located at $218 \mathrm{~T} \rightarrow \mathrm{C}, 224 \mathrm{~T} \rightarrow \mathrm{C}, 242 \mathrm{~A} \rightarrow \mathrm{C}, 246 \mathrm{~T} \rightarrow \mathrm{A}, 248 \mathrm{~T} \rightarrow \mathrm{C}, 305 \mathrm{~T} \rightarrow \mathrm{C}$, and $329 \mathrm{C} \rightarrow \mathrm{T}$. A $246 \mathrm{~T} \rightarrow \mathrm{A}$ mutation in exon 1 induced an $\mathrm{R} / \mathrm{K}$ change in 83 amino acids of the protein polypeptide chain. Most SNPs in the genome were located in intron regions because exons are relatively conserved. In this study, some mutations were identified in exons of the MyoDlb gene. The phenomenon indicates that the MyoDIb gene disappeared during evolution through non-exon conservation; the $M y o D$ gene in rainbow trout is rich in polymorphisms and the genetic variability is high. Furthermore, the S6 locus showed high PIC (0.582), indicating that the locus had a higher degree of genetic variability and a larger selection potential.

In pig, the TCBB diplotype of the myogenin gene had desirable effects on the total number of fibers, fiber cross-sectional area, and loin eye area compared to the other diplotypes. Moreover, the diplotype had the highest $\mathrm{pH}$ value in muscle and all meat quality traits were near the upper limit of the normal range, including the traits reddish pink, firm, and nonexudative pork (Kim et al., 2009). Intron 2 of the $M y o D$ gene was associated with carcass traits in cattle (Tian et al., 2007). However, in goat, the $M y o D$ gene was found to be correlated with body size traits (Zhang et al., 2007). The association between the $M y o D$ gene and meat quality traits has not been reported previously in fish. In this study, the mutated polymorphisms were examined using correlation analysis to determine their influence on meat quality traits in rain- 
bow trout. The results indicated that different genotypes in the S3 and S5 loci had significant impacts on muscle fiber density, muscle fiber diameter, and dry matter indicators $(\mathrm{P}<0.05)$. The SNPs in the MyoDla and MyoDlb genes in rainbow trout were associated with muscle fiber traits and may play important roles in the meat quality traits of rainbow trout. Thus, these genes can be used as candidate genes to affect the muscle fiber traits of rainbow trout.

Molecular marker-assisted selection is used widely in upland cotton (Guo et al., 2005), rice (Sun et al., 2006), wheat (Anderson, 2007), sorghum (Knoll and Ejeta, 2008), and roses (Biber et al., 2009). Particularly, in upland cotton, the pyramiding of 2 quantitative trait loci controlling high fiber strength identified through marker-assisted selection greatly improved the selection efficiency of cotton fiber strength (Guo et al., 2005). In dairy cattle, breeding across-family marker-assisted selection using selective genotyping strategies has been reported previously (Ansari-Mahyari et al., 2008). However, in fish, this method is rarely used. Only in Chinese shrimp, microsatellite markers, including simple sequence repeats were examined for their usefulness in breeding (Dong et al., 2006). Thus, SNPs in the S3 and S5 loci should be examined in larger populations and used for molecular marker-assisted selection for meat quality traits in rainbow trout.

\section{REFERENCES}

Anderson JA (2007). Marker-assisted selection for Fusarium head blight resistance in wheat. Int. J. Food Microbiol. 119: 51-53.

Ansari-Mahyari S, Sørensen AC, Lund MS, Thomsen H, et al. (2008). Across-family marker-assisted selection using selective genotyping strategies in dairy cattle breeding schemes. J. Dairy Sci. 91: 1628-1639.

Biber A, Kaufmann H, Linde M, Spiller M, et al. (2009). Molecular markers from a BAC contig spanning the Rdr1 locus: a tool for marker-assisted selection in roses. Theor. Appl. Genet. 120: 765-773.

Braun T, Buschhausen-Denker G, Bober E, Tannich E, et al. (1989). A novel human muscle factor related to but distinct from MyoD1 induces myogenic conversion in 10T1/2 fibroblasts. EMBO J. 8: 701-709.

Braun T, Bober E, Winter B, Rosenthal N, et al. (1990). Myf-6, a new member of the human gene family of myogenic determination factors: evidence for a gene cluster on chromosome 12. EMBO J. 9: 821-831.

Buckingham M (1992). Making muscle in mammals. Trends Genet. 8: 144-149.

Davis RL, Weintraub H and Lassar AB (1987). Expression of a single transfected cDNA converts fibroblasts to myoblasts. Cell 51: $987-1000$.

Dong SR, Kong J, Zhang QW, Liu P, et al. (2006). Pedigree tracing of Fenneropenaeus chinensis by microsatellite DNA markers genotyping. Acta Oceanol. Sin. 25: 151-157.

Falconer DS and Mackay TFC (1996). Introduction to quantitative genetics, 4th edn. Longman Group, Essex.

Guo WZ, Zhang TZ, Ding YZ, Zhu YC, et al. (2005). Molecular marker assisted selection and pyramiding of two QTLs for fiber strength in upland cotton. Yi Chuan Xue Bao 32: 1275-1285.

Hughes SM, Taylor JM, Tapscott SJ, Gurley CM, et al. (1993). Selective accumulation of MyoD and myogenin mRNAs in fast and slow adult skeletal muscle is controlled by innervation and hormones. Development 118: 1137-1147.

Kablar B, Krastel K, Ying C, Asakura A, et al. (1997). MyoD or Myf-5 differentially regulate the development of limb versus trunk skeletal muscle. Development 124: 4729-4738.

Kim JM, Choi BD, Kim BC, Park SS, et al. (2009). Associations of the variation in the porcine myogenin gene with muscle fibre characteristics, lean meat production and meat quality traits. J. Anim. Breed. Genet. 126: 134-141.

Knoll A, Nebola M, Dvorák J and Cepica S (1997). Detection of a DdeI PCR/RFLP within intron 1 of the porcine MYOD1 (MYF3) Iocus. Anim. Genet. 28: 308-322.

Knoll J and Ejeta G (2008). Marker-assisted selection for early-season cold tolerance in sorghum: QTL validation across populations and environments. Theor. Appl. Genet. 116: 541-553.

Liang ZQ, Li CW, Ou LY, Yu CS, et al. (2009). Analysis and Evaluation of the Nutrients Compositions of the Muscle of Sinilabeo decorus Tungting (Nichols). Acta Nutr. Sin. 31: 411-413.

Macqueen DJ and Johnston IA (2008). An update on $M y o D$ evolution in teleosts and a proposed consensus nomenclature to accommodate the tetraploidization of different vertebrate genomes. PLoS One 3: e1567.

Massari ME and Murre C (2000). Helix-loop-helix proteins: regulators of transcription in eucaryotic organisms. Mol. Cell. 
Biol. 20: 429-440.

Olson EN, Brennan TJ, Chakraborty T, Cheng TC, et al. (1991). Molecular control of myogenesis: antagonism between growth and differentiation. Mol. Cell Biochem. 104: 7-13.

Óvilo C, Fernández A, Rodríguez MC, Nieto M, et al. (2006). Association of MC4R gene variants with growth, fatness, carcass composition and meat and fat quality traits in heavy pigs. Meat Sci. 73: 42-47.

Picard B, Lefaucheur L, Berri C and Duclos MJ (2002). Muscle fibre ontogenesis in farm animal species. Reprod. Nutr. Dev. 42: 415-431.

Pownall ME, Gustafsson MK and Emerson CP Jr (2002). Myogenic regulatory factors and the specification of muscle progenitors in vertebrate embryos. Annu. Rev. Cell Dev. Biol. 18: 747-783.

Rescan PY and Gauvry L (1996). Genome of the rainbow trout (Oncorhynchus mykiss) encodes two distinct muscle regulatory factors with homology to myoD. Comp. Biochem. Physiol. B Biochem. Mol. Biol. 113B: 711-715.

Rudnicki MA, Braun T, Hinuma S and Jaenisch R (1992). Inactivation of $M y o D$ in mice leads to up-regulation of the myogenic HLH gene Myf-5 and results in apparently normal muscle development. Cell 71: 383-390.

Rudnicki MA, Schnegeisberg PN, Stead RH, Braun T, et al. (1993). MyoD or Myf-5 is required for the formation of skeletal muscle. Cell 75: 1351-1359.

Sun LH, Wang CM, Su CC, Liu YQ, et al. (2006). Mapping and marker-assisted selection of a brown planthopper resistance gene bph2 in rice (Oryza sativa L.). Yi Chuan Xue Bao 33: 717-723.

te Pas MFW and Visscher AH (1994). Genetic regulation of meat production by embryonic mouse muscle formation - a review. Anim. Breed. Genet. 111: 404-412.

Tian L, Xu SZ, Yue WB, Li JY, et al. (2007). Relationship between genotypes at MyoD locus and carcass traits in cattle. Yi Chuan 29: 313-318.

Urbański P and Kurył J (2004). New SNPs in the coding and 5' flanking regions of porcine MYOD1 (MYF3) and MYF5 genes. J. Appl. Genet. 45: 325-329.

van Wijk HJ, Arts DJ, Matthews JO, Webster M, et al. (2005). Genetic parameters for carcass composition and pork quality estimated in a commercial production chain 1. J. Anim. Sci. 83: 324-333.

Voytik SL, Przyborski M, Badylak SF and Konieczny SF (1993). Differential expression of muscle regulatory factor genes in normal and denervated adult rat hindlimb muscles. Dev. Dyn. 198: 214-224.

Weintraub H (1993). The MyoD family and myogenesis: redundancy, networks, and thresholds. Cell 75: 1241-1244.

Wyszyńska-Koko J, Pierzchała M, Flisikowski K, Kamyczek M, et al. (2006). Polymorphisms in coding and regulatory regions of the porcine MYF6 and MYOG genes and expression of the MYF6 gene in m. longissimus dorsi versus productive traits in pigs. J. Appl. Genet. 47: 131-138.

Yu LY, Bai JJ, Ye X, Li SJ, et al. (2009). Molecular cloning and identification of single nucleotide polymorphisms of MyoD in largemouth bass (Micropterus salmoides). J. Fish. China 33: 1-8.

Zhang HJ, Chen H, Fang XT, Zhang RF, et al. (2007). Association of variations in MyoD family of genes with body measurement traits in goat. Yi Chuan 29: 1077-1082. 